\title{
Histological Studies of the Prenatal Development of the Human Thyroid Gland
}

\author{
By \\ Akira Taki \\ Department of Anatomy, Nagoya University School of Medicine \\ (Directors: Profs. Drs. Chikat aro Togari and Shooich Sugi y a ma)
}

\section{Introduction}

Regarding the histological differentiation of the human thyroid gland in prenatal life, there are a few detailed reports ( $N$ or $\mathrm{ris}$, 16 and '18; T $\mathrm{T} \mathrm{kash} \mathrm{im} \mathrm{a} \mathrm{and} \mathrm{Hara}$, '34), and the observations are concerned chiefly with the morphogenesis and histogenesis of the primordium and follicles of relatively early life, and no attempt has been made to elucidate fully the histology of the pattern of the definitive parenchyma in later life. Recently, E. $\mathrm{Ham}$ me $\mathrm{r}$ and $\mathrm{H}$. Loeschcke ('36/37), by the use of the wax plate reconstruction method on the thyroid glands of human infants, demonstrated that acinus units are present in the lobules and that the units are comparable in structural plan with those of the exocrine gland. To solve the problem whether such a pattern may exist in differentiation of the human thyroid gland in prenatal life or not is now indispensable for an understanding of the thyroid structure of the human adult. The primary purpose of this study is to clarify this point, and the second to determine certain important critical stages in differentiation of the human thyroid gland. The author thereby hopes that this paper may present fundamental data for the background of other investigations and for further consideration of this organ under pathological conditions.

\section{Materials and Methods}

A total of 165 japanese embryos and fetuses were examined and 144 of them were subjected to detailed histological observations (table 1). Intrauterine age of the embryos and fetuses was estimated by measuring the crown rump lengths, crown heal lengths and men- 
Akira Taki

Table 1. Numbers of human embryos and fetuses examined.

\begin{tabular}{|c|c|c|c|c|c|c|c|}
\hline CHL & CRL & Weeks & No. of cases & $\mathrm{CHL}$ & CRL & Weeks & No. of cases \\
\hline \multirow[t]{35}{*}{$\mathrm{mm}$} & $3 \mathrm{~mm}$ & 5 & $2(2)$ & 125 & $-\mathrm{mm}$ & 14 & $1(1)$ \\
\hline & 4 & 5 & $2(2)$ & 130 & - & 14 & 1 (1) \\
\hline & 5 & 5 & $3(3)$ & 140 & - & 15 & 1 (1) \\
\hline & 6 & 6 & $5(5)$ & 150 & - & 15 & 1 (1) \\
\hline & 7 & 6 & $3(3)$ & 160 & 120 & 16 & 1 (1) \\
\hline & 8 & 6 & $4(4)$ & 170 & - & 16 & 1 (1) \\
\hline & 9 & 7 & $3(2)$ & 174 & - & 16 & $1(1)$ \\
\hline & 10 & 7 & $4(4)$ & 180 & - & 16 & 1 (1) \\
\hline & 11. & 7 & $2(2)$ & 190 & - & 17 & 1 (1) \\
\hline & 12 & 7 & $2(2)$ & 195 & - & 17 & 1 (1) \\
\hline & 13 & 7 & $3(3)$ & - & - & 14 & 1 (1) \\
\hline & 14 & 8 & $3(3)$ & 200 & - & 15 & $3(3)$ \\
\hline & 15 & 8 & $4(3)$ & - & - & 16 & 1 (1) \\
\hline & 16 & 8 & $2(2)$ & - & - & 17 & $1(0)$ \\
\hline & 17 & 8 & $2(2)$ & 210 & - & 18 & $1(0)$ \\
\hline & 18 & 8 & $4(3)$ & 215 & 150 & 19 & $2(2)$ \\
\hline & 19 & 9 & $2(2)$ & 220 & - & 19,22 & $2(2)$ \\
\hline & 20 & 9 & 2 (2) & 230 & - & 19 & $2(2)$ \\
\hline & 21 & 9 & $6(5)$ & 240 & - & 19 & $2(1)$ \\
\hline & 22 & 9 & 1 (1) & 245 & - & 20 & 1 (1) \\
\hline & 23 & 9 & $4(3)$ & 250 & - & 20 & $1(0)$ \\
\hline & 24 & 9 & 1 (1) & - & - & 20 & $1(0)$ \\
\hline & 25 & 9 & $2(2)$ & 260 & - & 21 & $2(2)$ \\
\hline & 26 & 9 & 1 (1) & 265 & - & 21 & 1 (1) \\
\hline & 27 & 9 & 1 (1) & 270 & - & 22,24 & $3(3)$ \\
\hline & 28 & 9 & $2(2)$ & 280 & - & 18 & 1 (1) \\
\hline & 29 & 10 & 1 (1) & 285 & - & 23 & $1(0)$ \\
\hline & 30 & 10 & $3(2)$ & 290 & 175 & 23 & $1(0)$ \\
\hline & 31 & 10 & $2(1)$ & 295 & - & 21 & 1 (1) \\
\hline & 32 & 10 & 1 (1) & 300 & - & 24 & $2(1)$ \\
\hline & 35 & 10 & $2(2)$ & 315 & - & 24 & $1(0)$ \\
\hline & 36 & 10 & $1(1)$ & 330 & - & 25 & 2 (1) \\
\hline & 37 & 10 & 1 (1) & 335 & 220 & 25 & 1 (1) \\
\hline & 38 & 10 & 1 (1) & 340 & - & 25 & 1 (1) \\
\hline & 40 & 10 & 1 (1) & 350 & - & 26 & 1 (1) \\
\hline 55 & 43 & 11 & 1 (1) & 360 & - & 26 & $2(2)$ \\
\hline 57 & 48 & 11 & 1 (1) & 370 & - & 27,29 & $2(2)$ \\
\hline $60 *$ & 50 & 11 & $2(1)$ & 375 & 240 & 28 & $2(2)$ \\
\hline 63 & $52^{*}$ & 11 & $1(0)$ & 380 & - & 28 & 1 (1) \\
\hline 71 & - & 12 & $1(1)$ & 390 & - & 29 & 1 (1) \\
\hline- & - & 11 & 1 (1) & 395 & - & 29 & 1 (1) \\
\hline 90 & $70 *$ & 12 & $2(2)$ & 400 & - & 31 & $2(2)$ \\
\hline- & - & 12 & 3 (1) & 410 & - & 31 & 1 (1) \\
\hline 95 & $73^{*}$ & 13 & 1 (1) & 420 & - & 32 & 1 (1) \\
\hline 100 & - & 13 & 1 (1) & 455 & 270 & 33 & 1 (1) \\
\hline 110 & 80 & 13 & $3(3)$ & 470 & - & 34 & 1 (1) \\
\hline 115 & - & 13 & 1 (1) & 500 & - & 36 & 1 (1) \\
\hline 123 & - & 14 & 1 (1) & 520 & - & 40 & 1 (1) \\
\hline
\end{tabular}

( ): No. of cases, used for histological observations.

* : Presumed values of CRL and CHL, derived from observed CHL and CRL by two formulas, $\mathrm{CRL}: \frac{2 \mathrm{CHL}+3}{3}$ and $\mathrm{CHL}: \frac{3 \mathrm{CRL}-3}{2}$ (Fischel, '29) 
strual age (in weeks). Embryos and fetuses ranging from $3 \mathrm{~mm}$ in crown rump length to $90 \mathrm{~mm}$ in crown heal length were fixed in toto, chiefly in Zenker-formol fluid, and some in Car no y's fluid or $10 \%$ neutral formol, embedded in paraffin, and sectioned at 5 to $8 \mu$ serially, transversely or sometimes sagittally. Thyroid glands in fetuses measuring over $90 \mathrm{~mm}$ were removed from the neighboring organs and treated in the same way. The sections prepared were stained mainly by M a y e r's hematoxylin and eosin, sometimes by $\mathrm{H}$ e i d e nha i n's iron hematoxylin, by W e i g e r t's resorcin fuchsin stain for elastic fibers, van Gie son's stain and azan stain for connective tissue fibers and $\mathrm{B}$ i e l $\mathrm{s} \mathrm{ch} \mathrm{ow} \mathrm{k}$ y's silver impregnation for argyrophilic fibers. The silver impregnation method was employed for examining the changing patterns of the thyroid differentiation. Some of the sections fixed in Zenker-formol fluid and $\mathrm{C}$ a $\mathrm{r}$ noy's fluid were stained by periodic acid-Schiff's method and Best's method for demonstrating glycogen and other substances, in combination with saliva digestion.

$15 \cdot \mathrm{mm}$

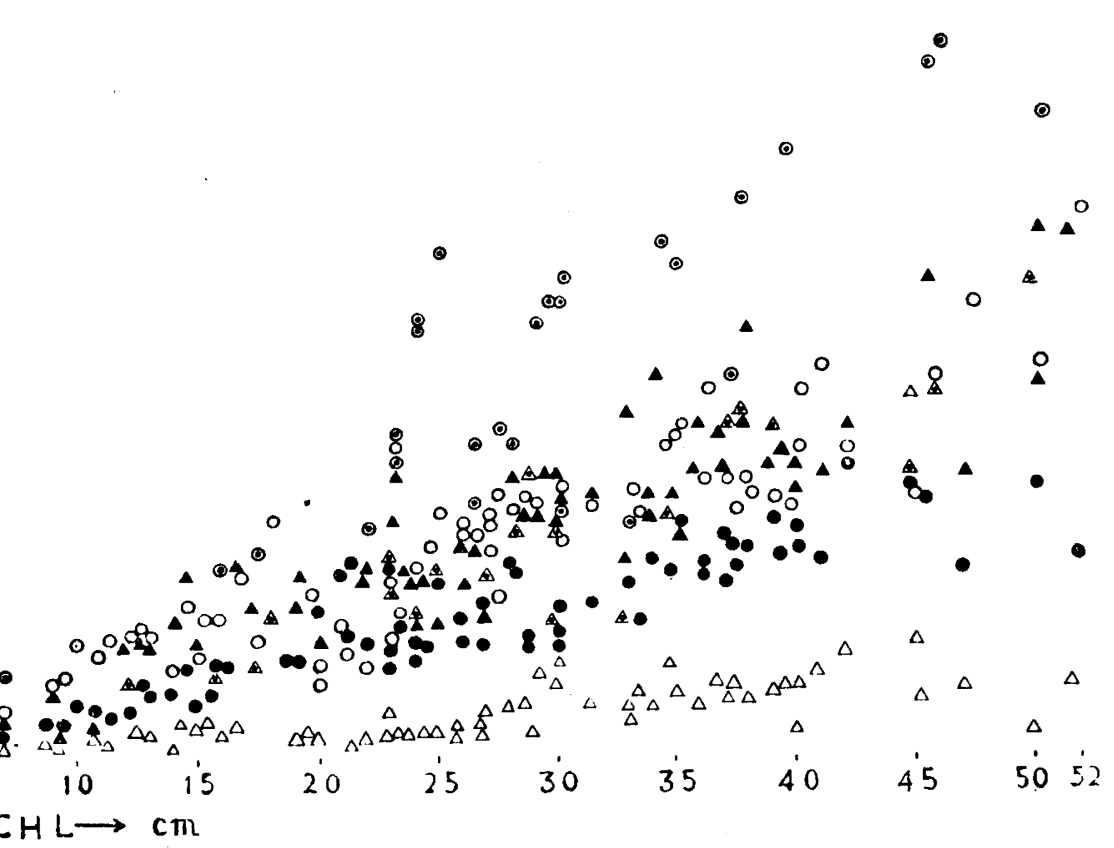

Fig. 1. Growth of the human thyroid gland in fetal life, estimated from the ventrodorsal, transverse, and cephalocaudal diameters of the lateral lobe and isthmus. Lateral labe- $\bigcirc$ : ventrodorsal diameter; $O$ : transverse diameter; $\bigcirc$ : cephalocaudal diameter. Isthmus- $\Delta:$ ventrodorsal diameter; $\Delta$ : transverse diameter; $\Delta$ : cephalocaudal diameter. 
Investigations of growth change of the thyroid primordium and gland were made by measuring the transverse, ventrodorsal and cephalocaudal diameters of the lateral lobes and isthmus by the usual method (fig. 1). To examine various forms of development of the primordia and follicles, wax plate reconstruction models were made by the use of serial transverse sections which were impregnated by silver according to $\mathrm{Bi}$ e $\mathrm{ls} \mathrm{chow} \mathrm{sky's} \mathrm{method.}$

\section{Observations}

The Morphogenesis and Growth of the Thyroid Gland In the 3 to $5 \mathrm{~mm}$ CRL stages (5 weeks) the thyroid primordium appeared as a globular or elliptic body with a stalk arising from a shallow evagination of the pharyngeal floor, suggesting the later Foramen caecum, and located in the mesenchymal tissue above and in front of the primitive heart and Truncus arteriosus (figs. 3 and $18_{1-2}$ ). The surface became rougher soon later. Some of the primordia were already separated from the pharyngeal floor at the end of these stages.

In the 6 to $9 \mathrm{~mm}$ CRL stages ( 6 to 7 weeks) the primordium was completely detached and free from the floor, and grew laterally to an initial bilobed structure, frequently with a remnant of the stalk (Ductus thyreoglossus) (figs. $18_{3-6}$ ). The primordium was situated upon the Truncus arteriosus which moved caudad with the primitive heart. In these stages the primordium had one or a few completely closed cavities which sometimes contained a cloudy substance stained faintly with eosin (fig. 4). The cavities appeared to develop individually as independent spaces, which later partly communicated with each other, and finally opened to the outside. In the 10 to $13 \mathrm{~mm}$ CRL stages (7 weeks), the thyroid primordium grew further laterally and came to have the lateral lobes and isthmus, and was situated anterior to the primitive trachea (figs. $18_{7-8}$ and 6). The primordium as a whole was sheet-like. The lateral lobes enclosed the carotid arteries (figs. 6 and $18_{9}$ ).

From the $14 \mathrm{~mm}$ to $31 \mathrm{~mm}$ CRL stages ( 8 weeks), the lateral lobes underwent a marked increase in size becoming an ellipsoid, while the isthmus grew at a slower rate (fig. 1). Near full term, the cephalocaudal diameter of the lateral lobes became about 15 -fold, the ventrodorsal about 7-fold and the transverse about 12-fold in size that of the $15 \mathrm{~mm}$ stage ( 8 weeks). On the other hand, the ventrodorsal diameter of the isthmus became about 7 -fold and the transverse about 
8-fold increase in size.

Follicle Formation Until the 6 to $9 \mathrm{~mm}$ CRL stages (6 weeks) the primordium, containing a few intraprimordial cavities (fig. 4), consisted in great part of cell conglomerates. Somewhat later (10 to $13 \mathrm{~mm}$ stages, 7 weeks), cell plates appeared added to these conglomerates. Some of the plates were produced by opening to the outside of the intraprimordial cavities (figs. 6 and 7). The cell conglomerates and cell plates became increased and some of them became separated into cell cords and cell bands by ingrowth of mesenchymal elements. The cell plates and cell cords were usually two or three cells in thickness and 15 to $17 \mu$ in width, while the cell conglomerates were several cells in thickness and 21 to $34 \mu$ in width (figs. 6 to 9).

These arrangements became maximum in number in the $31 \mathrm{~mm}$ CRL stage (10 weeks) and then gradually decreased although they were recognized up to $90 \mathrm{~mm}$ CHL stage (12 weeks). Some of the epithelial cells in these different arrangements became arranged radially, showing the most primitive type of follicle (figs. 8 and 9). In the center of these radial groups intercellular spaces appeared and were transformed into small cavities, which later were occupied by secretory substances stained poorly with eosin. As development continued, the cell cords and cell plates exhibited varicosities and string-of-pearl appearances (fig. 10), with cavitation and differentiation of the epithelial cells, finally developing into the definitive follicles. Three types of follicle were distinguishable: namely, (1) the primitive type with radial cells and a central intercellular space, (2) the transitional type containing a distinct cavity, but whose cells were still immature and (3) the definitive follicle.

The primitive follicles appeared for the first time in the $14 \mathrm{~mm}$ CRL stage (8 weeks) in a very small number, and increased in number, reaching their maximum in the 32 to $48 \mathrm{~mm}$ CRL stages (10 to 11 weeks) (figs. 9 and 10). They were 21 to $25 \mu$ in diameter. With some fluctuations after the $50 \mathrm{~mm}$ CRL stage (11 weeks), they decreased in number, but maintained a relatively low proliferative level until full term. They were produced also through budding processes from the walls of transitional and definitive follicles, without passing through the cell cords or cell plate formation. The epithelial cells of these primitive follicles varied from the primordial epithelium to the follicle epithelium, depending upon whether they were derived from budding of the follicle walls, in which case they assumed the same appearance as the follicle cells. 
The transitional follicles began to appear from the $23 \mathrm{~mm}$ CRL stage $(9$ weeks) only in very small numbers, in the peripheral zone of the primordium, and were most numerous during the 32 to $48 \mathrm{~mm}$ CRL stages (10 to 11 weeks). Despite possessing distinct cavities of various sizes, most of the transitional follicles contained none. Small numbers of them in the peripheral zone had only traces of secretory substance, which was stained poorly with eosin or with periodic acid$\mathrm{S} \mathbf{c}$ h if $\mathrm{f}$ 's stain.

From the $50 \mathrm{~mm}$ CRL stage (11 weeks), a slow gradual conversion into almost definitive follicles took place. Some of the transitional follicles situated peripherally came to have half-mature colloid which was feebly stained with eosin, but red purple by periodic acid$\mathrm{Schiff}$ 's stain, and on the verge of developing into definitive follicles. The variously developing types of immature follicle were directly connected with each other without communication of their cavities and formed follicular conglomerates, bands, cords and networks (figs. 11 and $19_{1-2}$ ). From the $32 \mathrm{~mm}$ CRL stage (10 weeks) on, some of the transitional follicles preceded others in growth, and became unproportionaliy large, often irregular-shaped, premature follicles. Such follicles had often several primitive follicles as buds. Their epithelium was highly columnar. The cavity contained nothing or only small amounts of secretory substance. The secretory substance was periodic acid-S $\mathrm{ch}$ if f positive, red purple, vacuolated and almost identical in appearance with the typical colloid found later.

Follicles The definitive follicles made their first appearance at the $95 \mathrm{~mm}$ CHL stage (13 weeks) (fig. 14) and increased in number and size with age. They were, for the most part, round to oval in section, but some of them showed different degrees of irregularity. Large follicles were present more frequently at the periphery of the gland, and small follicles in the central part. The dimensions of the large follicles near full term reached about a three to 4 -fold increase over the $95 \mathrm{~mm}$ CHL stage (figs. 2 and 14). Follicles of different sizes, including primitive follicles as buds, were connected directly with each other. This fact was also confirmed by preparing wax plate reconstruction models (figs. $19_{3-7}$ ). The connections were complicated and formed follicular cords or bands, conglomerates and networks. The cords and bands appeared as a kind of beaded chain with alternate swellings and constrictions (figs. 19 ${ }_{4-6}$ and 17). In some of the follicular conglomerates, small follicles and primitive follicles were arranged as satellites around large follicles (figs. 17 and $19_{5-6}$ ), and they formed 
an arboreal system (Drüsenbäumchen) or a follicle family. At full term, however, there was found a considerable number of dissociated follicles.

Some of the large follicles showed an irregularity of shape and possessed a number of hollow out-projections of their wall, which appeared as independent follicles separated clearly by argyrophilic fibers in other consecutive serial sections. Their epithelium was highly columnar.

Epithelial Cells In early stages (3 to $13 \mathrm{~mm} \mathrm{CRL.} 5$ to 7 weeks), the epithelial cells were closely packed, without distinct cell boundaries. The nuclei were resicular, with a weak chromatin reticulum and an eosinophilic nucleolus, and varied in size and contour. Generally the cells having large nuclei were found in greater numbers than those with small nuclei. In sections fixed by Zenker-formol fluid and stained with hematoxylin and eosin, these nuclei were colored slightly reddish violet. The cytoplasm had a clear, almost hyaline appearance with fine scattered granules. Glycogen was found as granules in the cytoplasm but not in the nuclei (figs. 5 and 7 ).

In the 14 to $31 \mathrm{~mm}$ CRL stages ( 8 to 10 weeks), the epithelial cells did not show any marked difference from those above, and formed plates, bands, cords and conglomerates. Some of the epithelial cells underwent changes to exhibit cell boundaries although indistinct, and became triangular or low cubical to form primitive and transitional follicles. Glycogen was found also in the same manner (fig. 8), and especially in abundance in the supranuclear area. In the 32 to $48 \mathrm{~mm}$ CRL stages (10) to 11 weeks) the majority of the epithelial cells formed primitive and transitional follicles. Some of them became eosinophilic or faintly red purple with periodic acid-Schif f's stain in their apical portion, suggesting the forerunning sign of secretory activity. Glycogen was found also in the same manner (fig. 9).

From the $50 \mathrm{~mm}$ CRL to $90 \mathrm{~mm}$ CHL stages (11 to 12 weeks), the epithelial cells became cubical to columnar in some of the transitional follicles verging on maturity, and began to contain periodic acid$\mathrm{Sch}$ if $\mathbf{f}$ positive secretory droplets in their apical portions. This positivity remained uninfluenced by saliva digestion. Glycogen was found (figs. 12 and 13).

At the $95 \mathrm{~mm}$ CHL stage (13 weeks) the epithelial cells became completely definitive follicle cells. They exhibited relatively distinct cell boundaries and had somewhat smaller nuclei than before. The nuclei showed moderately dense chromatin networks. The cytoplasm 
was finely granular and slightly eosinophilic, and sometime loaded with a few secretory droplets, which were stained red purple by periodic acid-Schiff's stain. The positivity was not changed by saliva digestion. Glycogen was still found in a very small amount at the $95 \mathrm{~mm}$ CHL stage, but soon later disappeared.

The follicle cells were cubical to columnar, and were sometimes highly columnar in large follicles, chiefly in those placed peripherally, while they were generally cubical in small follicles in the central part of the gland. The colloid cells began to appear in the $95 \mathrm{~mm}$ CHL to $110 \mathrm{~mm}$ CHL stages (13 weeks), and were red purple with periodic acid-Schiff's stain (figs. 15 and 16). Their positivity remained uninfluenced by saliva digestion.

Mitoses of the epithelial cells were numerous during the early period. They continued to increase in number until the $50 \mathrm{~mm}$ CRL stage (11 weeks). Mitoses of the follicle cells were also numerous but gradually decreased in number towards full term.

In proportion with the length of time elapsing after death, follicle cells appeared to be more or less extensively desquamated into the follicle cavity.

Colloid Until the $31 \mathrm{~mm}$ CRL stage (10 weeks), secretory products failed to be found. From the $32 \mathrm{~mm}$ CRL stage (10 weeks) onwards, traces of secretory substance, which were poorly stained with eosin or periodic acid-Schiff's stain, and believed to be the so-called precolloidal substance, began to appear in some of the transitional follicles placed peripherally, and increased at a very slow rate towards the $48 \mathrm{~mm}$ CRL stage (11 weeks). However, in the 32 to $48 \mathrm{~mm}$ CRL stages (10 to 11 weeks) transitional follicles containing none dominated the entire primordium.

From the $50 \mathrm{~mm}$ CRL stage (11 weeks) on, half-mature colloid, which was stained red purple with periodic acid-S $\mathrm{ch}$ if f's stain but feebly stained with eosin, occurred in transitional follicles maturing to definitive follicles, in the peripheral zone of the gland (fig. 13), and increased in amount slowly towards the $90 \mathrm{~mm}$ CHL stage (12 weeks). The positivity of periodic acid-Schiff reaction was not changed by saliva digestion.

At the $95 \mathrm{~mm}$ CHL stage (13 weeks), typical colloid prevailed over the whole gland. The colloid was moderately eosinophilic and red purple with periodic acid-S ch if f's stain, and was partly vacuolated (figs. 14 to 16). The colloid found at the periphery was more intensely stained than in the central part of the gland, and was partly eosino- 
philic and partly basophilic. The positivity for periodic acid-S c h if f's reaction remained unchanged by saliva digestion.

Capsule and Interstitial Connective Tissue Until the $10 \mathrm{~mm}$ CRL stage ( 7 weeks) mesenchymal tissue surrounded directly the thyroid primordium. From the $14 \mathrm{~mm}$ CRL stage (8 weeks) onward, the mesenchymal tissue and primitive capillaries invaded the parenchyma, preparatory to differentiation of the different cell arrangements. In the $14 \mathrm{~mm}$ stage the mesenchymal cells became possessed with slightly elongated nuclei, and exhibited frequent mitotic divisions. From the $16 \mathrm{~mm}$ CRL ( 8 weeks) on, argyrophilic fibers began to appear within the primordium and became increased towards later life, surrounding directly the different cell arrangements including primitive and transitional follicles (figs. 10 and 11). In the surrounding zone of the primordium, the argyrophilic fibers were arranged in layers with mesenchymal cells and formed a primitive capsule (fig. 10 ). In the $50 \mathrm{~mm}$ CRL stage (11 weeks) the mesenchymal tissue was changed to young connective tissue which was arranged more densely than before.

In the $95 \mathrm{~mm}$ CHL stage (13 weeks) the connective tissue was arranged densely and formed better developed interstitial tissue and a capsule. The interlobular connective tissue, as part of the interstitial tissue, began to be found as such at the $95 \mathrm{~mm}$ stage, but was indistinct. In the $200 \mathrm{~mm}$ CHL stage (15 weeks), the interlobular connective tissue was relatively distinctly formed in the dorsal, medial and lower peripheral zones of the lateral lobe. The tissue contained many collageneous and argyrophilic fibers but only a few elastic fibers. Some of the argyrophilic fibers were distributed in the follicles and associated follicle groups to form a fine reticular layer around the follicle epithelium (fig. 17). Other argyrophilic fibers surrounded circularly the capillaries.

Blood Vessels Primitive ordinary capillaries appeared first in the interior of the primordium in the $14 \mathrm{~mm}$ CRL stage (8 weeks) and increased in number slowly, while sinusoidal capillaries occurred somewhat later ( $16 \mathrm{~mm} \mathrm{CRL}, 8$ weeks). Both types of capillary were increased markedly at about the $48 \mathrm{~mm}$ CRL stage (11 weeks) with frequent occurrence of mitotic divisions of endothelial cells. With the dominant occurrence of the definitive follicles (95 mm CHL, 13 weeks) the capillaries were increased further with repeated division of endothelial cells, and formed plexuses around the follicles and associated follicle groups. 
Primitive arteries appeared for the first time at the periphery of the primordium in the $27 \mathrm{~mm}$ CRL stage (9 weeks) and in its interior in the $30 \mathrm{~mm}$ CRL stage (10 weeks). They gradually increased in number in the peripheral zone as well as in the central zone of the gland, and appeared complete as such in the $95 \mathrm{~mm}$ CHL stage (13 weeks). These arteries had a distinct lamina elastica interna. No arterial buds were found in the branching points of the arteries. Veins in the interior of the primordium were delayed in appearing, and were found first in the $30 \mathrm{~mm}$ CRL stage (10 weeks). They appeared to develop from some of the sinusoidal capillaries, and ran with the arteries early in the wide interstitial connective tissue and later in the interlobular connective tissue. In the $215 \mathrm{~mm}$ CHL stage (19 weeks), most of the veins appeared considerably developed and in the $300 \mathrm{~mm}$ CHL stage (24 weeks) some of them came to have a weak elastic layer. Most of the veins found in full term, however, were composed only of endothelium and adventitia, without muscle fibers.

\section{Discussion}

Biochemical, enzymological, radioautographic and radiochromatographic experiments have suggested that there are some stages of functional differentiation in thyroid glands of mammals in prenatal life. $\mathrm{R}$ a $\mathrm{nkin}$ ('41) investigated some stages of change of the content of iodine compounds in the thyroid gland of pigs in fetal life. W olff, $\mathrm{Ch}$ a i of $\mathrm{f}$ and $\mathrm{N}$ i c hols ('49) observed stages of accumulation of thyroxine-like and other iodine compounds in fetal bovine thyroid gland. M c Alpine ('55) investigated different stages of change of alkaline glycerophosphatase in the developing thyroid gland cf albino rats in embryonic life. W a te $\mathrm{rm}$ a $\mathrm{n}$ and $\mathrm{G}$ or b m a n ('56) found some stages of functional differentiation in the fetal rabbit by the use of radioautography and radiochromatography.

The histological observations also make it possible to divide the prenatal development of the human thyroid gland into the following three stages related to glandular activities: (1) early differentiation stage ( 3 to $13 \mathrm{~mm} \mathrm{CRL}, 5$ to 7 weeks); (2) preparatory differentiation stage subdivisible into three parts $(14 \mathrm{~mm}$ CRL to approximately 90 $\mathrm{mm} \mathrm{CHL,} 8$ to 12 weeks); and (3) follicle stage (95 to $520 \mathrm{~mm} \mathrm{CHL,}$ 13 weeks to full term). By definition these stages are clearly classified, but it is true that the histological structure of the gland undergoes no corresponding sudden characteristic change at the beginning of 
each stage.

At the end of the early differentiation stage, the thyroid primordium is still devoid of its characteristic endocrine architecture, and growth including completion of the definitive form and topographical location of the primordium are noted without the development of its own vascular system. As found in the epithelia of the pharyngeal floor, parathyroids and ultimobranchial bodies, glycogen is found as granules in the epithelium of the thyroid primordium (figs. 5 and 7). There is a considerable number of information on the early embryonic development corresponding to this stage ( $\mathrm{S}$ u d le r, '02, Broman, '11; Grosser, '11; King sbury, '15; Norris, '18; Takashima and $\mathrm{Hara}$, '34; Sagalitzer, '41; Fujū, '50; Politzer and Stockinger, '54; Orts-Llorca et al., '58). Fischer ('29) described in his textbook that the thyroid primordium arises from the pharyngeal floor forming the thyreoglossal duct and then moves toward the bifurcation of the Truncus arteriosus which moves also caudad with the heart, and finally becomes situated anterior to the trachea as a bilobed structure. The data, however, are a little at variance with those by different investigators. Sudler reported that the primordium arises as a rounded eminence on the ridges uniting the first pair of branchial arches at the end of the 2 nd week $(2.1 \mathrm{~mm})$, has a solid stalk in 4 weeks and grows laterally to a bilobed structure at the early 5 th week $(9 \mathrm{~mm})$, indicating an U-shaped structure in the latter part of the same week. B r o ma n wrote that at the beginning of the 4 th embryonic week the primordium is a bilobed structure with a thyreoglossal duct containing two cavities in its caudal end. According to $\mathrm{Norris}$, in the two to $4 \mathrm{~mm}$ stages the primordium arises as an extensive but shallow evagination from the mesobranchial region lying between the ventral extremities of the first two pairs of gill pouches, in the 4 to $5 \mathrm{~mm}$ stages appears as a globule with or without cavities or as a bilobed structure containing two cavities, in the 6 to $7 \mathrm{~mm}$ stages comes to be provided with a solid or hollow stalk, and finally in the 3.9 to $7 \mathrm{~mm}$ stages shows a separated globular body. Hammar stated that in $10 \mathrm{~mm}$ embryos the primordium appears as an epithelial plate, situated upon the Truncus arteriosus, and later produces two lobes and an isthmus. Takas h $\mathrm{ma}$ and $\mathrm{Hara}$ described that the primordium arises as a flask-shaped structure from the pharyngeal floor in the $6 \mathrm{~mm}$ stage, is separated becoming an ovoid body with cavities in the $6.5 \mathrm{~mm}$ stage, and has two lateral 
lobes and an isthmus in the $10 \mathrm{~mm}$ stage. $F u j \bar{u}$ found that the primordium arises from an evagination of the pharyngeal floor in the $4.8 \mathrm{~mm}$ stage and is later transformed from an unpaired solid body to a horse-shoe-shaped structure. S a g litzer, Orts-Llor c a et al., Politzer and Stockinger reported the occurrence of the Tuberculum thyreoideum as an initial primordium in the mesobranchial area.

The present results are in closed agreement with those of these authors (figs. 3 to 7 , and $18_{1-9}$ ): In the $3 \mathrm{~mm}$ CRL stage (5 weeks) the thyroid primordium arises as an unpaired solid globular projection from the mesobrachial area of the pharyngeal floor, and connects with the floor by forming a short solid or hollow stalk (thyreoglossal duct) in the three to $5 \mathrm{~mm}$ stages (5 weeks), and is situated above and in front of the heart and Truncus arteriosus. From the $6 \mathrm{~mm}$ stage ( 6 weeks) on the primordium begins to lose its connection with the floor and moves downward and forward to the bifurcation of the Truncus arteriosus. In the $13 \mathrm{~mm}$ stage (7 weeks) the primordium is transformed into a sheet-like, arch-shaped bilobed structure and is

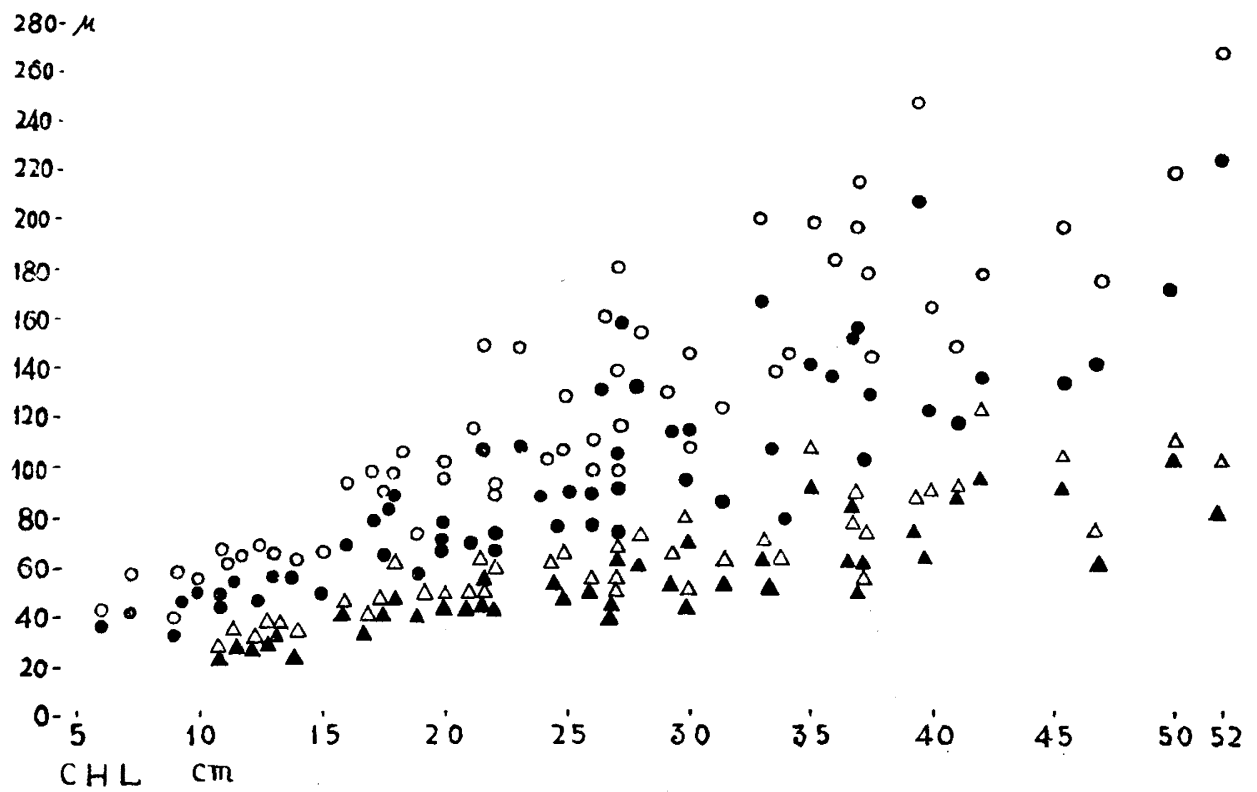

Fig. 2. Development of dimensions averaged of large follicles representative of each fetal stage. In the peripheral zone of the gland- $O$ : long diameter; $:$ short diameter. In the central zone- $\Delta:$ long diameter; $\boldsymbol{\Delta}$ : short diameter. 
situated anterior to the trachea. Later, the lateral lobe undergoes a marked increase while the isthmus grows at a retarded rate (fig. 1).

Nor r is ('18) found a number of closed cavities in the primordium in about the $7 \mathrm{~mm}$ stage (cavity formation stage), which later open to the outside by ingrowth of mesenchymal tissue. In agreement with Norris' data, the author found a few closed cavities in the primordium in the 6 to $13 \mathrm{~mm}$ stages. The cavities of ten contain cell detrituses and cloudy substance stained with eosin, very soon to open to the outside, and take a part in forming the cell plates (figs. 4 and 7). The thyreoglossal duct remains occasionally as a remnant in the middle part of the primordium in the early differentiation stage (figs. $18_{3-9}$ ).

The next stage is the preparatory differentiation stage. This stage is characterized by the increased formation of cell plates and cords in the first part (14 to $31 \mathrm{~mm}$ CRL stage, 8 to 10 weeks) (fig. 8 ), the increased formation of primitive follicles and transitional follicles in the second part ( 32 to $48 \mathrm{~mm}$ CRL stages, 10 to 11 weeks) (figs. 9 and 10), and the initial production of half-mature colloid in the third part (50 mm CRL to $90 \mathrm{~mm}$ CHL stages, 11 to 12 weeks) (fig. 13). The primordium comes to have an intimate relation with the developing vascular system. Conglomerates, cords, bands and plates of epithelial cells are completely or incompletely surrounded by ordinary and sinusoidal capillaries, and later primitive and transitional follicles are enclosed by them.

The epithelial cells of various arrangements including primitive and transitional follicles contain glycogen granules (figs. 8, 9, 12 and 13).

Kölliker (1879), Streiff (1897), B r o man ('11), H a m mar ('25), Pulaski ('29) and Stefko ('34) stated that anastomosing epithelial cylinders become tubular, in which varicose dilatations occur, and then are constricted off into primary follicles by ingrowth of mesenchymal tissue. On the other hand, Gros ser ('11) observed in the $55 \mathrm{~mm}$ stage that the cell cords become beaded by cavity formation and are constricted off into follicles. v. Gie r ke ('11) described that networks of solid cell cords are segmented into many round cell masses, which form later a cavity through secretion and are transformed into follicles. King s bury ('15) reported that in the 32 to $40 \mathrm{~mm}$ stages follicle cavities are found in the solid cell cords which arise by breaking down of cell plates. Norris ('18) rejected the tubular theory of Kölliker, Broman and others, 
and We ge lin ('26) and Wils on ('27) also agreed with Norris. The time of occurrence of immature follicles differs according to various investigators. According to $\mathrm{N}$ or $\mathrm{r}$ is ('16) early primary follicles begin to be formed in the 20 to $24 \mathrm{~mm}$ stages (CRL). L i v in i ('22) found first follicles in the 20 to $22 \mathrm{~mm}$ stages. H a m ma r ('25) found the formation of small empty follicles in the 24.2 to $27 \mathrm{~mm}$ stages. Bucciante and Maspes ('30) observed early primary follicles in the $16.5 \mathrm{~mm}$ stage. $\mathrm{Tak}$ a s i ma and $\mathrm{Hara}$ ('34) observed first follicles in the 20 to $25 \mathrm{~mm}$ CRL stages. F u j u ('50) found the formation of radial cell groups in the cell cords in the 16 to $17.5 \mathrm{~mm}$ stages.

The present investigations do not support the tubular theory and indicate that the initial formation of primitive follicles occur at the $14 \mathrm{~mm}$ CRL stage ( 8 weeks) in the anastomosing cell cords, bands and plates. The primordial parenchyma represents later networks consisting of cords, bands, plates and conglomerates of primitive and transitional follicles (figs. 10 and 11). Contrary to the data of some authors, the primitive follicles produced are not always separated and remain associated.

Cooper ('25) found secretion beginning in the form of palecoloured droplets in some follicles at the periphery of the gland by the middle of intrauterine life. N o r r is ('16) found a hazy, granular substance in some of the large early follicles before the $60 \mathrm{~mm}$ CRL stage. Tak a s i ma and $\mathrm{Hara}$ ('34) reported the occurrence of cloudy substance in some of the immature follicles in the $37 \mathrm{~mm}$ CRL stage.

The present investigations indicate the following: Very weak production of secretory substance appears in extremely few of the transitional follicles in the peripheral zone of the primordium in the second part (32 to $48 \mathrm{~mm}$ CRL stages, 10 to 11 weeks) of the preparatory differentiation stage. The secretory substance is stained faintly with eosin or with periodic acid-S $\mathrm{ch}$ if f's method and very small in amount. Later (in the third part), the secretory substance becomes red purple as half-mature colloid with the latter method (50 $\mathrm{mm}$ CRL to $90 \mathrm{~mm}$ CHL stages, 11 to 12 weeks) (fig. 13).

The 90 to $95 \mathrm{~mm}$ CHL stages (12 to 13 weeks) may be suggested as a turning point. The follicle stage starts approximately at the $95 \mathrm{~mm}$ CHL stage (13 weeks). Definitive follicles containing typical colloid prevailed over the entire gland. Glycogen in follicle epithelium 3 reduced in amount and disappears soon later. The beginning 
of this stage also may correspond to a period from 12 to 14 weeks, during which time the thyroid gland has been reported to collect radioactive iodine with the occurrence of colloid $(\mathrm{C} \mathrm{h} \mathrm{a} \mathrm{p} \mathrm{man}$ et al., '48; Hodge s et al., '55). On the other hand, Elke s ('03) and $\mathrm{Hesselberg} \mathrm{('10)} \mathrm{found} \mathrm{colloid} \mathrm{in} 4$ months old fetuses. $\mathrm{King} \mathrm{s}$ b u r y ('15) found it in the $40 \mathrm{~mm}$ stage. Norris ('16) found it in the $60 \mathrm{~mm}$ CRL stage, L i vi $\mathrm{n}$ i ('22) in the $62 \mathrm{~mm}$ stage, $\mathrm{H} \mathrm{a} \mathrm{m} \mathrm{mar}$ ('25) in the $70 \mathrm{~mm}$ stage, C o o per ('25) in 6 months old fetuses, We ge lin ('26) in the 25 to $40 \mathrm{~cm}$ stages, P u lask i ('29) in $77 \mathrm{~mm}$ fetuses from $\mathrm{Ha} \mathrm{mburg}$ and in $85 \mathrm{~mm}$ fetuses from B e r n, T a ka$\mathrm{shima}$ and $\mathrm{Hara}$ ('34) in the $82 \mathrm{~mm}$ CRL stage and $\mathrm{Fuj} \overline{\mathrm{u}}$ ('50) in the $130 \mathrm{~mm}$ CHL stage.

The typical colloid found is often vacuolated and stained moderately eosinophilic, or partly eosinophilic and partly basophilic, and further deeply red purple by periodic acid-S $\mathrm{ch}$ if f's method. The colloid has been interpreted as indicating glycoprotein reactions (D e m p s e y, '55).

The follicles increase in size and number with age (fig. 2). Throughout this follicle stage large follicles are found chiefly in the peripheral zone and small follicles in the central part of the gland. This, with some exception, is in sharp contrast with the description of Wölfle r (1880), who distinguished two zones, cortical and medullary, the former being young and less developed, while the latter is old and better developed.

In general agreement with some of $\mathrm{H}$ e i d e $\mathrm{n} h$ a i n's ('21) results, the definitive follicles are connected with each other directly by their epithelial walls, and form associated conglomerates, anastomosing cords and networks of them (figs. 17 and $19_{3-7}$ ). This finding has been also described in the thyroid glands of some mammals ( $\mathrm{Yag}$ i$\mathrm{z}$ a wa, '56). This may be interpreted as a sign of proliferative activity through budding of definitive follicles and, on the other hand, as a sign of the remaining of the pattern of anastomosing cell cords, cell bands, cell plates and cell conglomerates to be replaced and masked by developing follicles. Even near full term this pattern is maintained, and associated follicles are often found.

According to $\mathrm{Z}$ ielinska (1894), thyroid lobules of newborn children contain one or more central tubular follicles which are surrounded by numerous solid and minute follicles, and this gives one an impression that the acinous glandular pattern may be present in the lobules. The tubules, designated as the "Zentralkanälchen," have 
been interpreted to be a germinal layer that produces other follicles in the lobule (Aschoff, '25 and his associates). Klose ('16) demonstrated in thyroid glands of newborn children the central canal which appears as a round to oval or branching large follicle, lined by high columnar epithelium. By the use of the wax plate reconstruction method, it was shown in thyroid glands of children that acinus units are present in the lobule and comparable in structural

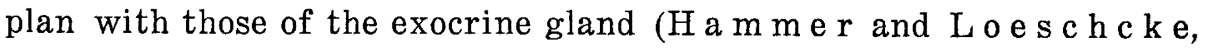
'34; L o e s c h cke, '36/37). The parenchyma of the lobule represent a branching tubular system consisting of collecting ducts of various orders and terminal portions. In section, the terminal portions appear as microfollicular cavities.

The wax plate reconstruction models demonstrated that such an exocrine glandular pattern is not found. In small numbers of the cases examined, the scattered occurrence in the lobules of large follicles is found, but their cavity does not always communicate with those of all the surrounding small follicles, but sometimes with a number of them.

With completion in differentiation of the definitive parenchyma in the follicle stage, the vascular system also reaches a status completed in structure. Hyperemia is also found usually in this stage. The arteries and veins run together within the interlobular connective tissue which is found indistinctly near the capsule. In the branching points of arteries, no arterial buds (S c h mi d t, 1894 ; H e sselberg, '10; Isenschmid, '10) are found. Pulaski ('29) found this structure in a $190 \mathrm{~mm}$ fetus. Capillaries, ordinary and sinusoidal, form networks around follicles and associated follicle groups, and sometimes indent the basal surfaces of the follicle epithelium. This resembles a picture described by B u c her ('40), but the capillaries are not intraepithelial.

There are rarely seen striated muscle fibers in the interstitial connective tissue as were found in man by Wölfler (1880) and Oseki ('10). On the other hand, thymic tissue islets are sometimes found in the central part of the thyroid lobe. Groschuff ('00) found thymic tissue islets derived from the ventral wall of the 4th pharyngeal pouch.

Finally one word is worthy of mention. The desquamation of follicle cells into the follicular cavity (H e s e l be r g, '10; St a e m$\mathrm{mle} \mathrm{r}$, '15) may be considered as a kind of post mortem change in general agreement with We gelin ('26) and P u laski ('29). 


\section{Summary}

A total of 165 japanese human fetuses were used in this study, and certain phases of glandular activity in prenated life were histologically elucidated. The thyroid development is divisible into the following three categories: (1) early differentiation stage, (2) preparatory differentiation stage, and (3) follicle stage.

The early differentiation stage (until $13 \mathrm{~mm}$ CRL, 7 weeks) includes the following. In 3 to $5 \mathrm{~mm}$ the thyroid primordium appears as a globular solid body with a stalk arising from the pharyngeal floor lying between the first pair of visceral pouches. Separated from the floor in the $6 \mathrm{~mm}$ stage, it descends ventrocaudad growing into various forms such as a plate, globule and bilobed structure, which contain a few intraprimordial cavities, and finally changes into an arch-like structure in the $13 \mathrm{~mm}$ stage. During this stage primordial epithelial cells are immature and arranged in conglomerates, and cords, bands and plates of two cell thickness. The nuclei are vesicular and of various sizes. The cytoplasm is sparsely granular and contains glycogen.

The preparatory differentiation stage is divided into three parts: The first part (14 to $31 \mathrm{~mm} \mathrm{CRL}, 8$ to 10 weeks) includes the increased formation of cell cords, bands and plates, the second (32 to $48 \mathrm{~mm}$ CRL, 10 to 11 weeks) the increased formation of primitive and transitional follicles, and the third (50 mm CRL to $90 \mathrm{~mm} \mathrm{CHL}$, 11 to 12 weeks) the production of half-mature colloid in transitional follicles. The substance is faintly stained with eosin and red purple by periodic acid-Schiff's method. The epithelial cells are still immature and contain glycogen.

At the $95 \mathrm{~mm}$ CHL stage (12 to 13 weeks) the follicle stage begins by the increasing formation of definitive follicles with typical colloid, at which stage capillaries forming plexus around the follicles occur in abundance. The colloid is moderately eosinophilic and periodic acid-S chiff positive. Most of the follicles connect with each other directly by their epithelial walls, and form follicular networks without forming a branching tubular system of exocrine glandular pattern. The epithelial cells become the follicle cells and come to contain no glycogen. The follicle cells contain often periodic acid$\mathrm{S} \mathrm{ch}$ if $\mathrm{f}$ positive secretory droplets. Some of them are transformed into colloid cells, whose cytoplasm is intensely positive to the same reaction. 
The author wishes to acknowledge his sincere thanks to Prof. Dr. Shooichi Sug i y a ma for his kind guidance throughout the course of this study. Further, the author is indebted to Prof. Dr. Chikataro $\mathrm{Tog}$ a $\mathrm{r}$ i for kind encouragement and help.

\section{Literature Cited}

A schoff, L.: Vorträge über Pathologie gehalten and den Universitäten und Akademien Japans im Jahre 1924. Gustav Fischer, Jena, 1925.

B a r g ma n n, W.: Die Schilddrüse in v. Möllendorff's Handb. mikr. Anat,, 6: 2 Tl., 1-136, Julius Springer, Berlin, 1939.

B r o man, I.: Entwicklung der Schilddrüse in Normale und abnormale Entwicklung des Menschen. 288-289, J. F. Bergmann, München, 1911.

Bucciante, L. and P.E. Maspes: Sulla morfogenesi della ghiandola tiroide nell'uomo ed in altri mammiferi. Arch. ital. Anat., 27:419-465; 1930 (cited from Bargmann, '39).

Bucher, O.: Intraepitheliale Kapillaren im Follikelepithel der Schilddrüse. Z. Zell forsch., $30: 432-438,1940$.

Chapman, E. M., G. W. Corner, Jr., D. Robinson and R.D. Evans: The collection of radioactive iodine by the human fetal thyroid. J. clin. Endocrin., 8: 717-720, 1948.

Cooper, E.W.: The histology of the more important human endocrine organs at various ages. 57-74, Oxford Med. Publ.. London, 1925.

Dempsey, E.W.: Histology and histochemistry in Werner's The Thyroid. 106-119, A Hoeber-Harper Book, N. Y.C., 1955.

Elke s, C.: Der Bau der Schilddrüse um die Zeit der Geburt. Inaug-Diss., Königsberg, 1903 (cited from Bargmann, '39).

F is che 1, A.: Lehrbuch der Entwicklung des Menschen. 319-333, Julius Springer, Wien, 1929.

Fujū, Y.: Embryological studies on the thyroid gland in mammals, with special reference to the formation of foramen caecum and ductus threoglossus. Part 1: human fetuses. Acta Inst. Anat. Nigatanensis, 25: 1-18, 1950.

v. Gi erke, E.: Die Schilddrüse in Ascoff's Pathologische Anatomie, 2. Aufl., 2: 891906, Gustav Fischer, Jena, 1911.

Groschuff, K.: Über das Vorkommen eines Thymussegmentes der vierten Kiementasche beim Menschen. Anat. Anz., 17: 160-170, 1900.

Grosser, O.: Entwicklung der Kiemendarmes und des Respirations-apparates in Keibel und Malls Handb. Entwicklungsgeschichte des Menschen., 2 : 436-461, S. Hirzel, Leipzig, 1911.

Hammar, I. A.: A quelle époque de la vie foetable de l'homme apparaissent le premiers signes d'une activité endocrine? Upsala Läkareforen. Förh., 30: 375-480, 1925.

$\mathrm{H}$ a m mer, E. und H. Loeschcke: Der feinere Bau der Schilddrüse und die sich aus ihm ergebenden Vorstellung über das Wesen der Proliferationsknospen. Zbl. Path., 60 : Erg.-H., 204-215, 1934.

Heidenhain, M.: Über verschiedene Typen im Bau der Schilddrüse. Anat. Anz., Erg.-Bd., 54: 141-151, 1921.

Hesselberg, C.: Die menschliche Schilddrüse in der fetalen Periode und in den 
ersten 6 Lebensmonaten. Frankf. Z. Path., 5 : 322-350, 1910.

Hodges, R.E., T.C. Evans, J.T. Bradbury and W.C. Ke et te l: The accumulation of radioactive iodine by human fetal thyroids. J. clin. Endocrin., 15: 661$667,1955$.

I se nschmid, R.: Zur Kenntnis der menschlichen Schilddrüse im Kindesalter, mit besonderer Berücksichtigung der Herkunft aus verschiedenen Gegenden im Hinblick auf die endemische Struma. Frankf. Z. Path., 5: 205-252, 1910.

Kingsbury, B.F.: The development of the human pharynx. Am. J. Anat., 18 : 329-397, 1915.

Klose, H.: Die pathologisch-anatomische Grundlage der Basedowschen Krankheit. Nach vergleichend pathologischen und klinischen Studien. Bruns' Beitr. klin. Chirur., 102, 1-12, 1916.

Kölliker, A.: Entwicklungsgeschichte des Menschen und der höheren Thiere. 875, W. Engelmann, Leipzig, 1879.

Livini, F.: Gli organi a secrezione interna nel periodo embrionale e fetale, nell'uomo. I. Ghiandola tiroide. Arch. ital. Anat., 18: 522-547, 1922 (cited from Bargmann, '39).

L oeschcke, E.: Morphologische Untersuchungen über den Bau der normalen und pathologischen Schilddrüse. Beitr. Path. Anat,, 98: 521-544, 1936/1937.

Mc Alpine, R. J.: Alkaline glycerophosphatase in the developing thyroid, parathyroid and thymus of the albino rat. Am. J. Anat., 96: 191-228, 1955.

Norris, E.H.: The early morphogenesis of the follicles of the human thyroid gland. Am. J. Anat., 20 : 411-448, 1916.

- The early morphogenesis of the human thyroid gland. Am. J. Anat., 24 : 443-465, 1918.

Orts.Llorca, F. and J.M. Genis Galve $z$ : On the morphology of the Primordium of the thyroid gland in the human embryo. Acta anat., 33: 110-121, 1958.

Oseki, S.: Zur Morphologie der Schilddrüse bei Japaner. Mitt. med. Ges. Tokio, $24: 1-56,1910$.

Politzer, G. und L. Stockinger: Die Frühentwicklung der Area mesobran. chialis beim Menschen. Acta Anat., 20 : 214-233, 1954.

Pulaski, A.: Vergleichende histologische Untersuchungen an fetalen Schilddrüsen aus Hamburg und Wien. Frankf. Z. Path., 38: 29-6், 1929.

$\mathrm{R}$ a n k in, R.M.: Changes in the content of iodine compounds and in the histological structure of the thyroid gland of the pig during fetal life. Anat. Rec., 80 : 123136, 1941.

Sagalit zer, K.E.: Contribution to the study of the morphogenesis of the thyroid gland. J. Anat., 75 : 389-393, 1941.

Schmidt, M. B.: Über Zellknospen in den Arterien der Schilddrüse. Virchows Arch., 137 : 330-348, 1894.

St a emmler, M.: Über Struma congenita und ihre Beziehungen zur Störungen der inneren Sekretion. Virchows Arch., 219: 226-245, 1915.

Stef ko, W.H.: Beiträge zur Kenntnis Konstitutions-anatomischer Besonderheiten der Organ (vom Standpunkte der postnatalen Entwicklung). Z. Konst.-lehre, 18: 287-310, 1934.

Streiff, J.J.: Uber die Form der Schilddrüsenfollikel des Menschen. Arch. mikr. Anat., 48: 579-586, 1897.

Sudler, M.T.: The development of the nose, and of the pharynx and its derivatives in man. Am. J. Anat., 1:391-416, 1902.

Takashima, R, und S. Hara: Uber die Entwicklung der Schilddrüse beim Ja. 
paner. Z. Anat., $102:$ 409-423, 1934.

W a terman, A.J. and A. Gorbman: Development of the thyroid gland of the rabbit. J. exper. Zool., 132: 509-538, 1956.

We g e $1 \mathrm{i} \mathrm{n}$, C.: Schilddrüse. in Henke-Lubarschs Handb. spez. path. Anat. u. Hist., 8: 1-47, Julius Springer, Berlin, 1926.

Wils o n, G.E.: The thyroid follicle in man: its normal and pathological configuration. Anat. Rec., $37: 31-60,1927$.

Wolf f, J., I. L. Chaik of $\mathrm{f}$ and $\mathrm{C}$. W. $\mathrm{Nichols,} \mathrm{Jr.:} \mathrm{The} \mathrm{accumulation} \mathrm{of} \mathrm{thyro-}$ xine-like and other iodine compounds in the fetal bovine thyroid. Endocrin., 44 : 510-519, 1949.

W ölf le r, A.: Über die Entwicklung und den Bau der Schilddrüse mit Rücksicht auf die Entwicklung der Kröpfe. Berlin, 1880 (cited from Wegelin, '26)

Y a g i z a wa, T.: The follicular pattern in the thyroid gland of maturing and mature mammals. Okajimas Fol. anat. jap., 29 : 93-115, 1956.

$\mathrm{Z}$ ieli ns k a, M.: Beiträge zur Kenntnis der normalen und strumősen Schilddrüse des Menschen und des Hundes. Virchows Arch., 136 : 170-194, 1894.

\section{Explanation of Plate Figures}

All figures, except for figure 3, represent photomicrographs of transverse sections of human thyroid glands (chiefly, lateral lobes).

3. $5 \mathrm{~mm}$ CRL (5 weeks). The thyroid primordium appears as an ellipsoid body with a stalk (thyreoglossal duct), connecting with the pharyngeal floor, and is situated above and in front of the Truncus arteriosus. Zenker-formol. hematoxylin and eosin. $\times 70$. Sagittal.

4. $6 \mathrm{~mm}$ CRL (6 weeks). The thyroid primordium is separated completely from the pharyngeal floor. It contains 4 independent closed cavities, in which cell detrituses are found. Carnoy. hematoxylin and eosin. $\times 250$.

5. $9 \mathrm{~mm}$ CRL (7 weeks). The thyroid primordium is separated from the pharyngeal floor. Primordial epithelium is arranged in plates, cords and conglomerates of cells, and contains glycogen. Carnoy. Best's stain. $\times 250$.

6. $13 \mathrm{~mm}$ CRL (7 weeks). The thyroid primordium appeared as an arch-shaped structure anterior to the trachea, and is divided into the lateral lobes and isthmus. Primordial epithelium is arranged in plates and conglomerates of cells. Zenker-formol. hematoxylin and eosin. $\times 70$.

7. $12 \mathrm{~mm}$ CRL (7 weeks). The right lateral lobe of the primordium contains two closed cavities. Primordial epithelium is arranged in plates and conglomerates, and contains glycogen in abundance. Carnoy. Best's stain. $\times 250$.

8. $27 \mathrm{~mm}$ CRL (9 weeks). Primordial epithelial cells form anastomosing plates and cords. Some of them are arranged radially to form primitive follicles. They contain glycogen granules in abundance. Carnoy. Best's stain. $\times 135$.

9. $32 \mathrm{~mm}$ CRL (10 weeks). Numerous primitive and transitional follicles are seen. They connect with each other and form the follicle networks. Primordial epithelial cells contain glycogen. Carnoy. Best's stain. $\times 135$.

10. $35 \mathrm{~mm}$ CRL ( 10 weeks). Primitive and transitional follicles form the follicle networks. Zenker-formol. Bielschowsky's silver impregnation. $\times 135$.

11. $50 \mathrm{~mm}$ CRL (10 weeks). Primitive and transitional follicles connect with each other, and form the follicle networks. Zenker-formol. Bielschowsky's silver impregnation. $\times 250$. 
12. $50 \mathrm{~mm}$ CRL ( 10 weeks). Primordial epithelial cells of primitive and transitional follicles contain glycogen. Zenker-formol. Periodic acid-Schiff's stain. $\times 800$.

13. $50 \mathrm{~mm}$ CRL (10 weeks). Some of the transitional follicles are verging on maturity, and come to have a small amount of half-mature colloid in their cavities. The substance is periodic acid-Schiff positive and not influenced by saliva digestion. Zenker-formol. Periodic acid-Schiff's stain. Saliva digestion. $\times 800$.

14. $95 \mathrm{~mm}$ CHL (13 weeks). Definitive follicles appear as dominating the entire gland. The colloid is typical, periodic acid-Schiff positive, and not changed in staining by saliva digestion. Primitive follicles are found as proliferative buds from the follicle walls. Carnoy. Periodic acid-Schiff's stain. Saliva digestion. $\times 135$.

15. $174 \mathrm{~mm} \mathrm{CHL}$ (16 weeks). Colloid cells are found. The cell body is periodic acid-Schiff positive. Zenker-formol. Periodic acid-Schiff's stain. Saliva digestion. $\times 800$.

16. $375 \mathrm{~mm}$ CHL (28 weeks). A colloid cell and secretory droplets are seen. Zenkerformol. Periodic acid-Schiff's stain. $\times 800$.

17. $375 \mathrm{~mm}$ CHL (28 weeks). Follicles connect with each other and form associated follicle groups (follicle families). Argyrophilic fibers surround them directly as a layer (Grenzschicht of Bucher). Zenker-formol. Bielschowsky's silver impregnation. $\times 135$.

18. Wax plate reconstruction models of the thyroid primordia in different early stages. $1-8: \times 500 ; 9: \times 250$.

1. $4 \mathrm{~mm}$ (anteroposterior view). 2. $5 \mathrm{~mm}$ (lateral view).

3. $6 \mathrm{~mm}$ (anteroposterior view). 4. $7 \mathrm{~mm}$ (anteroposterior view).

5. $8 \mathrm{~mm}$ (anteroposterior view). 6. $9 \mathrm{~mm}$ (anteroposterior view).

7. $10 \mathrm{~mm}$ (anteroposterior view). $8.11 \mathrm{~mm}$ (anteroposterior view).

9. $13 \mathrm{~mm}$ (anteroposterior view).

19. Wax plate reconstruction models of primordial and definitive thyroid tissues. 1 and 2: Primitive and transitional follicles connect with each other. 3 to 7 : Definitive follicles connect with each other without communication of their cavities, and form associated follicles groups. 1 and $2(\times 500): 71 \mathrm{~mm} \mathrm{CHL} ; 3$ and $4(\times 500): 200 \mathrm{~mm} \mathrm{CHL} ; 5(\times 571): 340 \mathrm{~mm} \mathrm{CHL} ; 6(\times 500): 455 \mathrm{~mm} \mathrm{CHL}$; $7(\times 571)$ : $520 \mathrm{~mm} \mathrm{CHL}$. 
Plate I
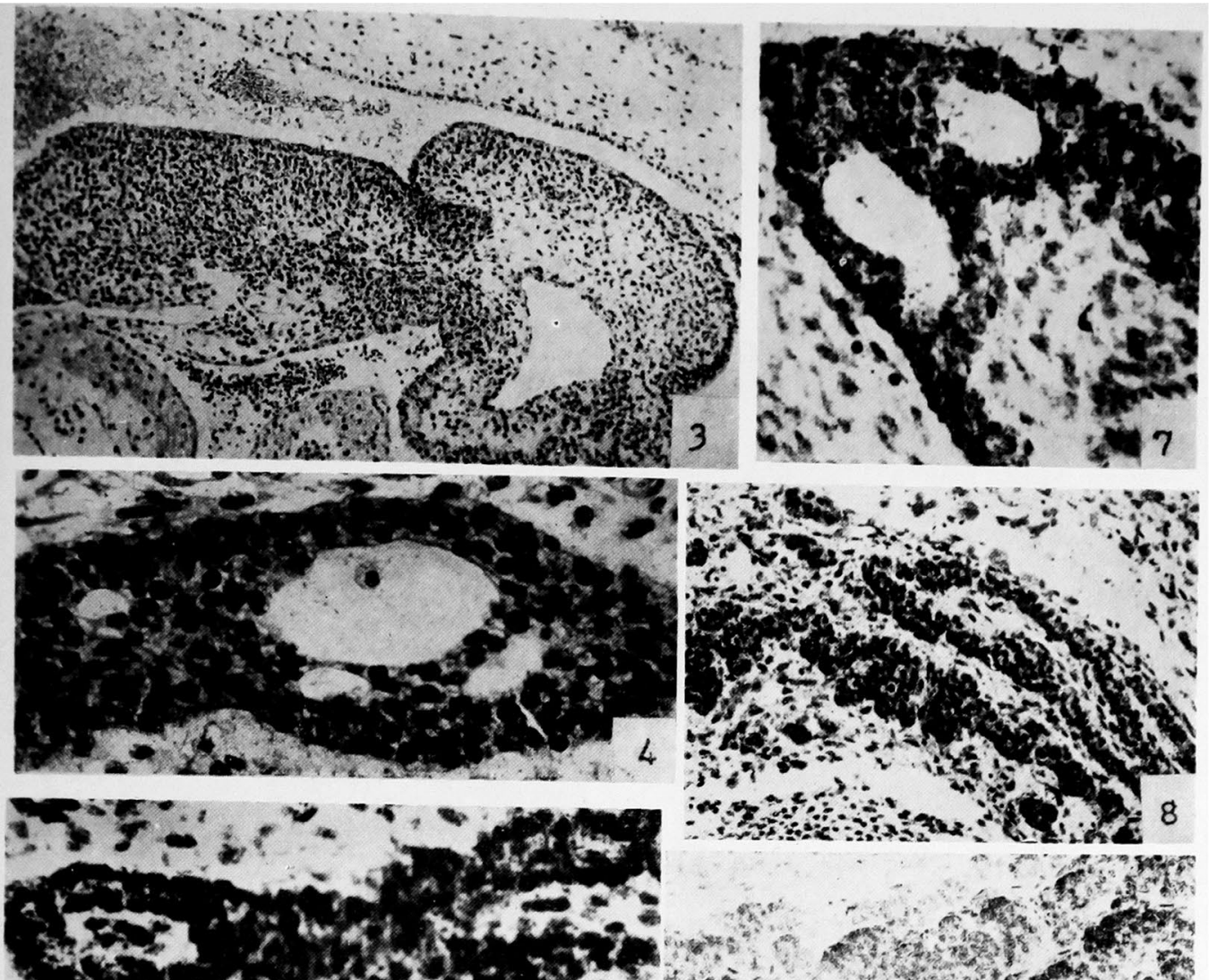

\section{3}

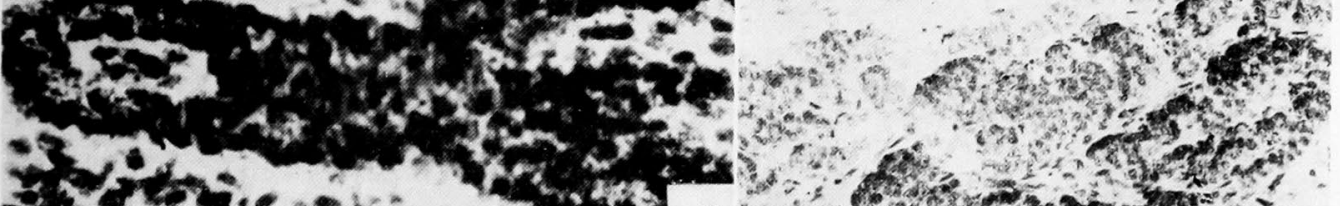
istor

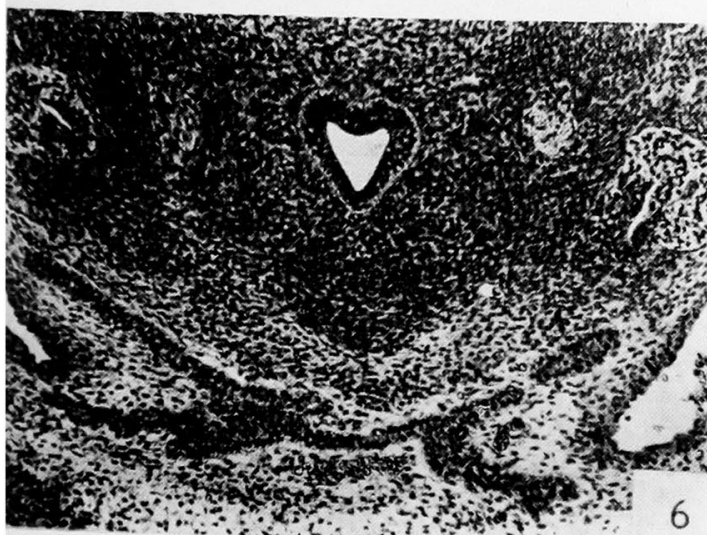

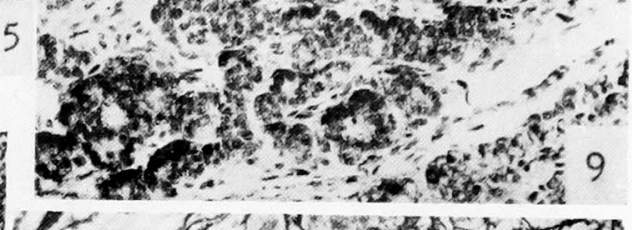
and

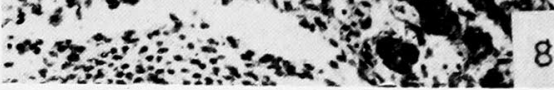

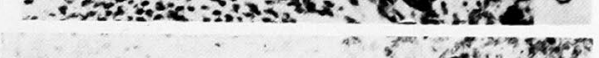
$2 x^{2}+2$

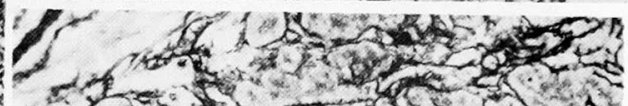

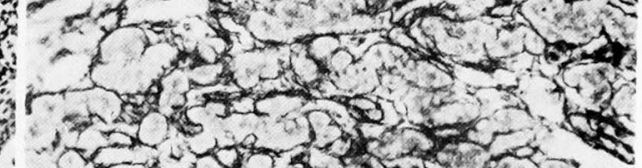

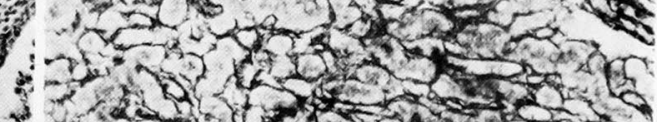

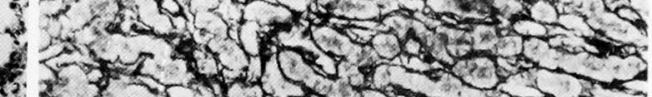

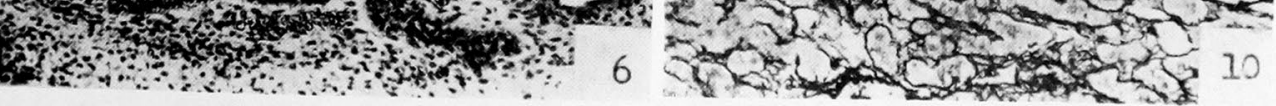

A. Taki 
Plate II
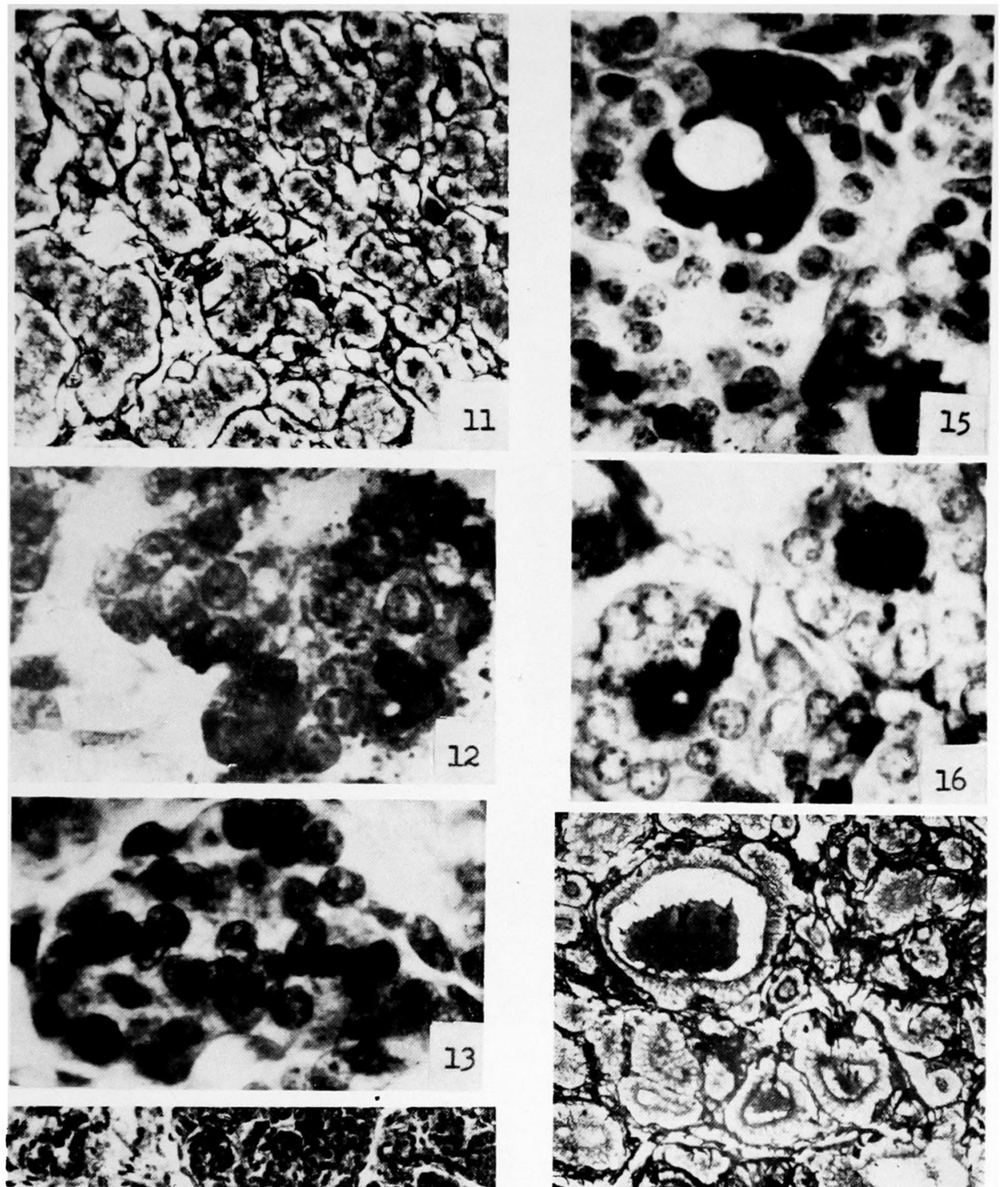

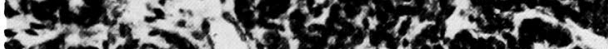

2.

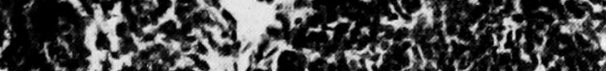

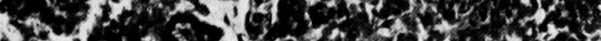

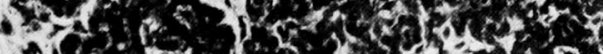

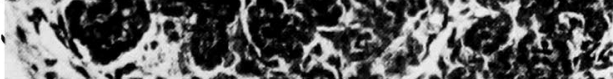

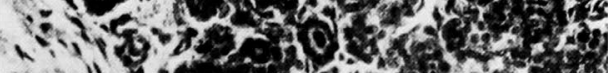

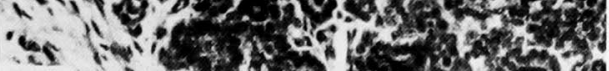

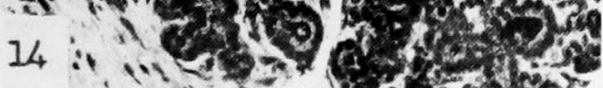

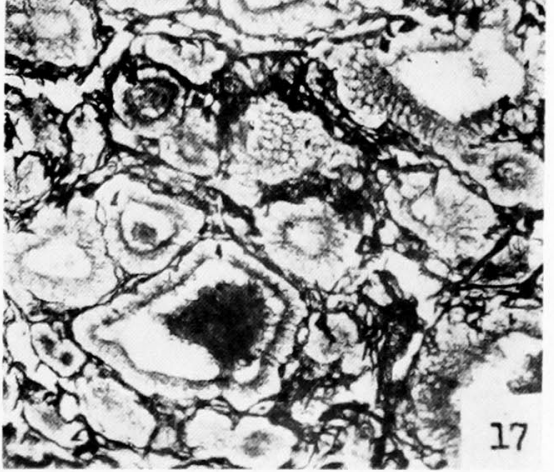

A. Taki. 
Plate 111
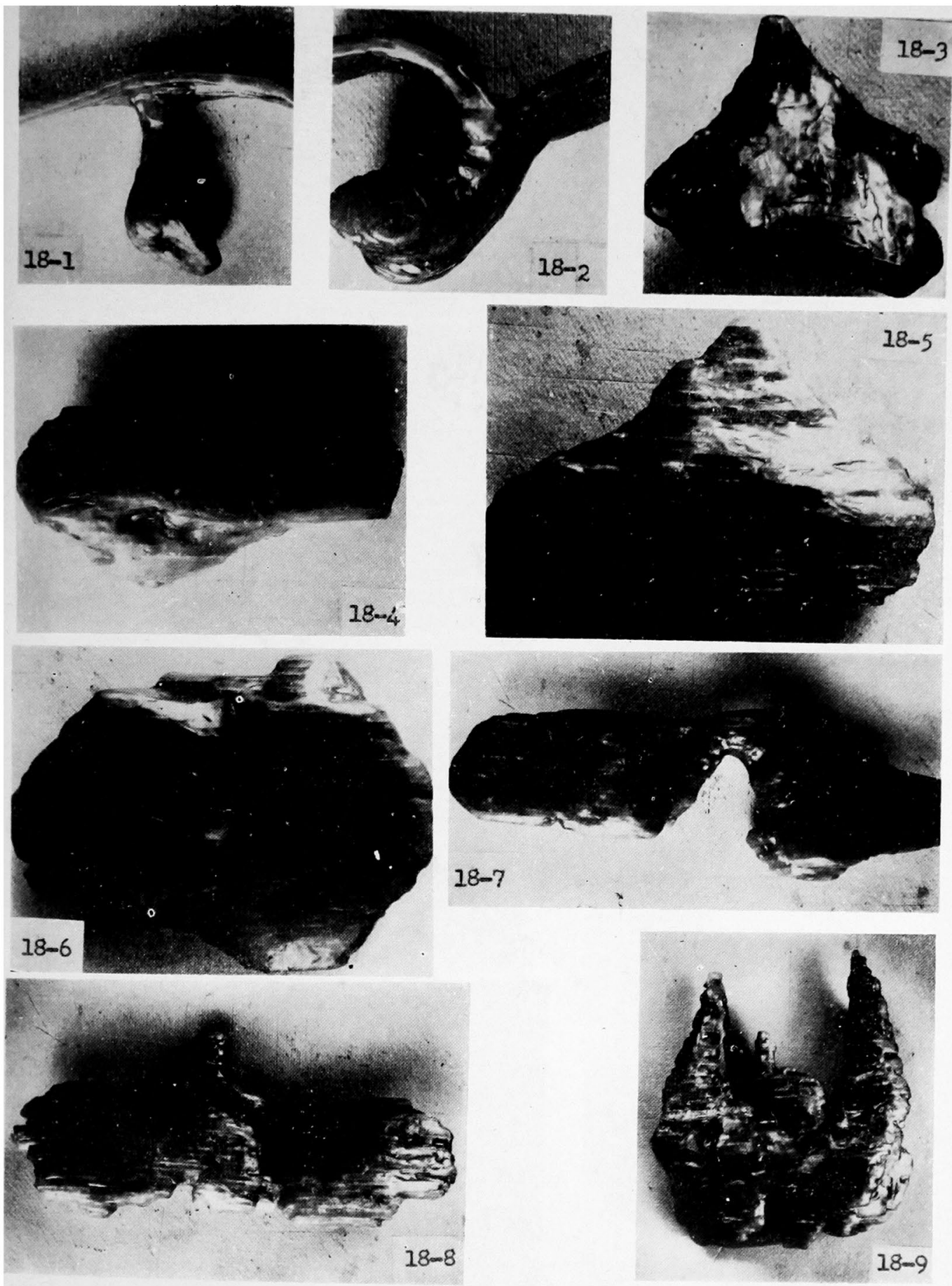

A. Taki 
Plate IV
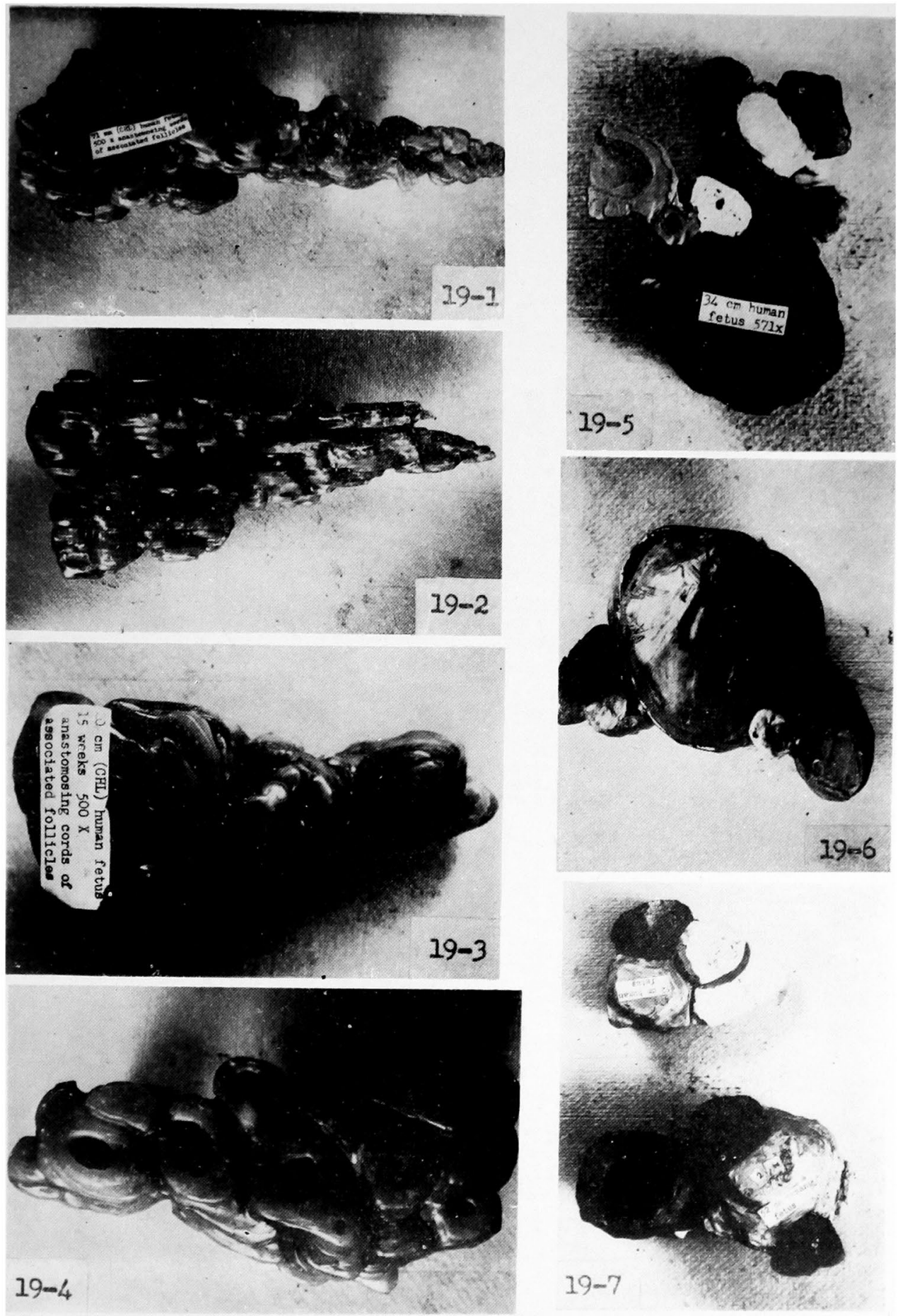

A. Taki 